\title{
Studi Komparatif Strategi Pembelajaran Inkuiri Ditinjau dari Kemampuan Kognitif Siswa SMA
}

\author{
Muhammad Fahrurrizal $^{1}$, Hadi Suwono ${ }^{1}$, Herawati Susilo ${ }^{1}$ \\ ${ }^{1}$ Pendidikan Biologi-Universitas Negeri Malang
}

\section{INFO ARTIKEL}

\section{Riwayat Artikel:}

Diterima: 24-04-2019

Disetujui: 22-06-2019

Kata kunci:
comparative study;
inquiry learning;
cognitive ability;
studi komparatif;
pembelajaran inkuiri;
kemampuan kognitif

Alamat Korespondensi:

Muhammad Fahrurrizal

Pendidikan Biologi

Universitas Negeri Malang

Jalan Semarang 5 Malang

E-mail: rizalpasca2018@um.ac.id

Pendidikan abad 21 merupakan pembelajaran yang mempersiapkan generasi baru dimana perkembangan teknologi informasi sebagai hubungan sosial maupun pengetahuan (American Association of School, 2007; Pacific Policy Research Center, 2010), utamanya sains sebagai terobosan dalam peningkatan sumber daya manusia dan sumber daya alam (Aikenhead, 2007). BSNP (2010) juga menjelaskan pentingnya kemampuan kognitif dalam bidang sains sebagai literasi kesehatan dalam pendidikan maupun kehidupan masyarakat. Paradigma abad 21 dalam pengetahuan sains menekankan pada peningkatan pengetahuan sebagai pembelajaran bermakna (Brookhart, 2010), termasuk kemampuan dalam berpikir, mengetahui, mengingat, dan menganalisis (Anderson \& Krathwohl, 2016) yang relevan dengan standar minimum kompetensi pendidikan nasional di Indonesia (Kemdikbud, 2013).

Pentingnya proses sains pada kemampuan kognitif setiap individu memiliki kemampuan dalam menemukan fakta, memahami konsep, dan menyusun prosedur yang pada akhirnya semua domain tersebut terdapat pada kehidupan sehari-hari siswa (Liewellyn, 2013; Zeidler \& Keefer, 2003). Salain itu, relevansi pendidikan abad 21 dan proses sains sangat menunjuang dalam ruang belajar siswa (Scott, 2015) dan Kemdikbud (2013) menjelaskan kompetensi dasar sains sebagai penerapan siswa dalam bidang kesehatan secara struktural terdapat pada silabus dengan beberapa kompetensi yakni 3.4 menganalisis struktur dan replikasi, serta peran virus dalam aspek kesehatan masyarakat, 3.5 menganalisis struktur dan cara hidup bakteri serta perannya dalam berbagai aspek kehidupan masyarakat, dan 3.7 menerapkan prinsip klasifikasi untuk menggolongkan jamur berdasarkan ciri-ciri, cara reproduksi, dan mengaitkan peranannya dalam kehidupan. Kementerian Pendidikan dan Kebudayaan (2016) menjelaskan kompetensi virus, bakteri, dan jamur sebagai dasar belajar literasi kesehatan dalam menunjang pengetahuan kognitif siswa pada tingkat menengah atas.

Hasil belajar kognitif didefinisikan sebagai gambaran sesuatu yang diketahui, dimengerti, dan diterapkan siswa setelah melalui proses pembelajaran (Sothayapetch, Lavonen, \& Juuti, 2013). Sejumlah hasil penelitian yang dilakukan oleh Sribekti, Ibrohim, \& Hidayat (2016), Susilowati, Rambitan, \& Ruchaemi (2017), dan Budiyono \& Hartini (2018) menunjukkan bahwa kemampuan kognitif siswa meningkat secara signifikan pada beberapa indikator, namun kurang pada indikator menganalisis dan prosedural. Hasil penelitian (Budiyono \& Hartini, 2018) menunjukkan bahwa siswa tingkat menengah atas memiliki kemampuan dasar menganalisis dan prosedural sehingga minimnya hasil belajar aspek investigasi. Berdasarkan kondisi faktual tersebut 
perlunya peningkatan strategi pembelajaran pada pendekatan investigasi yang melibatkan kemampuan analisis dan prosedural. NRC (2000) menjelaskan salah satu strategi pembelajaran pada pendekatan investigasi adalah inkuiri.

Kompleksitas pembelajaran inkuiri dalam kehidupan masyarakat (Banchi \& Bell, 2008), perlu integrasi strategi menjadi pembelajaran bermakna (Brookhart, 2010) dengan melibatkan isu-isu sains (socio scientific) sebagai landasan perspektif siswa dalam menstimulus berpikir kritis pada bidang kesehatan di masyarakat luas (Karisan \& Zeidler, 2016). socio scientific dengan investigasi mencakup aspek fakta, konsep, prinsip, dan prosedural (Keselman, 2003), maka dengan prinsip tersebut salah satunya adalah Inquiry. Inquiry merupakan pembelajaran yang berpusat pada siswa (Wang, Yingxu \& Ruhe, 2007) yang melibatkan siswa dalam proses penelitian (NRC, 2000; Yulaikah \& Alfindasari, 2016). Inkuiri terdiri atas beberapa level mulai yang terendah hingga tertinggi yakni Demonstrated Inquiry (DI), Structured Inquiry (SI), Guided Inquiry (GI), dan Self-Directed Inquiry (SDI) (Banchi \& Bell, 2008; Liewellyn, 2013). Beberapa tingkat level inkuiri memilki spesifikasi dan tujuan belajar yang berbeda yaitu SDI memiliki level inkuiri dengan pengembangan yang berpusat pada siswa pada semua tahapan pembelajaran, GI sebagai level inkuiri dibawah SDI sebagai dasar awal dalam menyiapkan pengalaman dasar penelitian, dan SI merupakan pembelajaran dengan level inkuiri dalam melatih penelitian dasar secara konseptual (Banchi \& Bell, 2008) sehingga perlunya komparatif strategi pembelajaran inkuiri dalam hasil belajar pengetahuan sains siswa.

\section{METODE}

Jenis penelitian ini merupakan penelitian eksperimen semu dengan desain penelitian nonrandomized control group postest design. Populasi dalam penelitian ini yaitu seluruh siswa kelas X MIPA SMAN 5 Malang pada tahun ajaran 2018/2019. Sampel pada penelitian ini adalah siswa semester I kelas X SMAN 5 Malang, yakni pada siswa kelas B1 (SSIq) sebanyak 35 siswa, kelas C1 (GI) sebanyak 36 siswa, dan kelas D1(SI) sebanyak 36 siswa. Penentuan sampel berdasarkan uji kesetaraan menggunakan hasil tes UN SMP 2018. Penelitian ini dilaksanakan pada bulan Agustus sampai Desember 2018 pada matapelajaran Biologi. Instrumen perlakuan ini terdiri atas Silabus, Rencana Pelaksanaan Pembelajaran (RPP), UKBM (Unit Kegiatan Belajar Mandiri), dan lembar observasi keterlaksanaan sintaks.

Instrumen pengukuran berupa tes kognitif berupa 25 soal pilihan ganda dengan empat kali ulangan yang dikembangkan berdasarkan Anderson \& Krathwohl (2016), yakni mengingat, mengamati, menerapkan, menganalisis, mengevaluasi dan mencipta. Tes dilaksakan dalam waktu mengerjakan selama 60 menit. Sebelum digunakan dalam penelitian, soal postes divalidasi dengan hasil menunjukkan bahwa semua soal dari setiap indikator memiliki nilai $\mathrm{p}>0.05$ yang artinya soal valid. Hasil uji daya menunjukkan bahwa pada tes kognitif sangat bagus. Hasil uji tingkat kesulitas menunjukkan bahwa setiap tes terdiri dari soal mudah, sedang, dan sulit. Uji validitas menggunakan uji Pearson Correlation dan uji dengan SPSS 22.0 for Windows. Hasil Uji validitas menunjukkan bahwa nilai $\mathrm{p}>0.05$ (Valid). Analisis data yang dilakukan pada penelitian ini, meliputi statistik deskriptif dan uji hipotesis (uji anova). Uji anova untuk membandingkan ketiga strategi pembelajaran dengan level signifikansi 0.05 .

\section{HASIL}

Tes kemampuan kognitif dikerjakan oleh siswa selama 45 sesudah pelaksanaan (Post-test) pembelajaran dengan SSIq, GI, dan SI. Pada satu semester, nilai siswa pada kelas SSIq berada pada rentangan 68 sampai 84 dengan rata-rata $77,45(\mathrm{SD}=$ 4.48), nilai siswa pada kelas GI berada pada rentangan 48 sampai 72 dengan rata-rata $64.44(\mathrm{SD}=5.95)$, dan nilai pada kelas SI 52 sampai 76 dengan rata-rata $65.83(\mathrm{SD}=5.99)$. Statistik deskriptif nilai kognitif (Tabel 1) menunjukkan bahwa ada perbedaan nilai kognitif siswa dari ketiga pembelajaran inkuiri serta menunjukkan peningkatan pada ketiga pembelajaran.

Tabel 1. Statistika Deskriptif Posttest Kognitif

\begin{tabular}{cccccc}
\hline Strategi & Nilai & Std. Deviasi & Std. Error & Min & Maks \\
\hline SSIq & 77.45 & 4.48 & 0.757 & 68 & 84 \\
\hline GI & 64.44 & 5.95 & 0.992 & 48 & 72 \\
\hline SI & 65.83 & 5.99 & 0.999 & 52 & 76 \\
\hline
\end{tabular}

Uji Anova (Tabel. 2) menunjukkan bahwa strategi SSIq, GI, dan SI dapat meningkatkan kemampuan kognitif secara siginifikan dengan nilai $\mathrm{F}=58.958$ dengan p-value sebesar $(0.000)<0.05$, artinya ada perbedaan yang signifikan antara ketiga kelas tersebut. Hasil uji lanjut dengan BNT (Tabel 3) menunjukkan bahwa SSIq berbeda signifikan dengan GI dan SI, namun tidak ada beda yang signifikan antara GI dan SI. Dengan kata lain, SSIq memberikan pengaruh terhadap hasil belajar yang lebih tinggi dibandingkan GI dan SI, sedangkan GI dan SI mempunyai pengaruh yang sama (hipotesis penelitian kesatu) diterima. Hasil anova dan uji lanjut BNT pada ketiga strategi pembelajaran disajikan secara berurutan pada tabel 2 dan 3.

Tabel 2. Uji Anova pada Strategi SDI-SSI, GI dan SI

\begin{tabular}{cccccc}
\hline Kognitif & Sum of Squares & df & Mean Square & F & Sig. \\
\hline Between Groups & 3608.397 & 2 & 1804.199 & 58.958 & 0.000 \\
\hline Within Groups & 3182.575 & 104 & 30.602 & & \\
\hline Total & 6790.972 & 106 & & & \\
\hline
\end{tabular}


Tabel 3. Hasil Uji Lanjut BNT

\begin{tabular}{ccccc}
\hline Kelas & (J) Kelas & Mean Difference (I-J) & Std. Error & Sig \\
\hline \multirow{2}{*}{ SSIq } & GI & $13.01270^{*}$ & 1.31316 & 0.000 \\
\cline { 2 - 5 } & SI & $11.62381^{*}$ & 1.31316 & 0.000 \\
\hline \multirow{2}{*}{ GI } & SSIq & $-13.01270^{*}$ & 1.31316 & 0.000 \\
\cline { 2 - 5 } & SI & -1.38889 & 1.30388 & 0.289 \\
\hline \multirow{2}{*}{ SI } & SSIq & $-11.62381^{*}$ & 1.31316 & 0.000 \\
\cline { 2 - 5 } & GI & 1.38889 & 1.30388 & 0.289 \\
\hline
\end{tabular}

* The mean difference is significant at the 0.05 level

Hasil perbandingan peningkatan setiap ulangan pada ketiga pembelajaran (Gambar 1) menunjukkan bahwa ulangan 1 terendah pada semua kelas terletak pada GI dengan nilai 49.5, sedangkan tertinggi terletak pada SSIq dengan nilai 60.8, ulangan 2 terendah pada semua kelas terletak pada GI dengan nilai 68.6, sedangkan tertinggi terletak SI 81.1, ulangan 3 terendah pada semua kelas terletak pada SI dengan nilai 69.5, sedangkan tertinggi terletak pada SSIq dengan nilai 80.8, dan ulangan 4 terendah pada semua kelas terletak pada SI dengan nilai 55.3, sedangkan tertinggi terletak pada SSIq dengan nilai 85.3. Hasil perbandingan setiap ulangan ketiga pembelajaran dapat dilihat pada gambar 1.

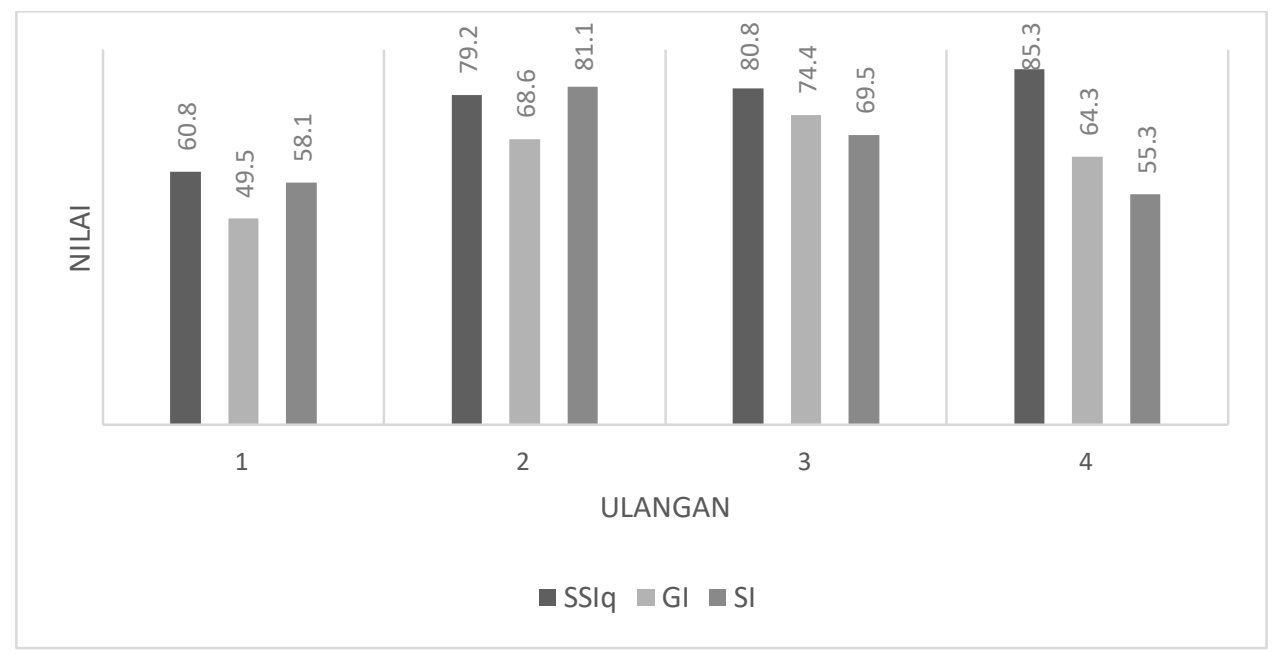

Gambar 1. Perbandingan Hasil Ulangan pada Ketiga Pembelajaran

\section{PEMBAHASAN}

SSIq, GI, dan SI merupakan strategi pembelajaran yang didasarkan pada inkuiri yakni pembelajaran yang melibatkan siswa dalam kerja ilmiah seperti ilmuan sebenarnya (Amien, 1988; Kim \& Tan, 2011; Liewellyn, 2013; NRC, 2000). Inkuiri meliputi tahapan identifikasi masalah, pengumpulan informasi, dan pemecahan masalah (Chu, Tse, \& Chow, 2011) yang relevan kemampuan pada dimensi proses kognitif menurut Anderson \& Krathwohl, (2016), meliputi mengingat, memahami, menerapkan, menganalisis, mengevaluasi, dan mencipta. Sejumlah hasil penelitian menunjukkan bahwa pembelajaran inkuiri lebih efektif dalam meningkatkan kemampuan kognitif (Abdurrahman, 2018; Anam, 2016). Persamaan proses pembelajaran pada kelas SSIq dengan GI, dan SI, siswa dituntut untuk belajar secara prosedural dan argumentatif sesuai informasi yang disajikan (Kinikin \& Hench, 2013), untuk mencari informasi yang cukup dalam menginterpretasi, mengasimilasi, dan mengorganisasi menjadi sebuah informasi yang bermakna. OECD (2015) juga menjelaskan bahwa pengetahuan siswa dan pemahaman menginterprestasikan suatu informasi terhadap materi pembelajaran sangat berkorelasi pada ranah kognitif yang melibatkan aktivitas otak dalam berpikir kritis.

Pada strategi SSIq dan GI dibutuhkan kemampuan rumusan pertanyaan, sejumlah pertanyaan bertujuan untuk mendorong siswa untuk mengeksplorasi konsep, mengarahkan siswa dalam melakukan penelitian, mengarahkan siswa dalam menyusun pengetahuan baru, dan mengarahkan siswa dalam menyusun argumen berdasarkan bukti yang didapatkan(Lee, Kim, Fl, \& Jeong, 2010; Şen, Yılmaz, \& Geban, 2015). Pembelajaran inkuiri pada tingkat SSIq, GI, dan SI menjadi pengembangan pada level siswa aktif yang berpusat pada siswa kolaboratif dan merupakan pembelajaran berbasis masalah (Laal \& Ghodsi, 2012; Liewellyn, 2013) yang dapat meningkatkan kemampuan menganalisis (C4) pada suatu masalah. Pembelajaran SSIq memiliki pengaruh kognitif secara signifikan dengan mengintegrasikan isu dalam kegiatan merumuskan masalah sebagai stimulus dalam ketertarikan dan pemahaman tentang konsep sains yang terkait fenomena yang terjadi dalam kehidupan (Burek, 2012), diikuti pembelajaran GI, SI dalam meningkatkan kemampuan siswa dalam mengambil keputusan kebenaran dari yang dibahas (Zo'bi, 2014). 
SSIq dan GI membantu siswa mengembangkan pikiran (Rodniam, 2015), termasuk mengembangkan pikiran dalam menyusun prosedur sains dengan menentukan sendiri sumber informasi yang diperlukan dan saling berinteraksi secara aktif, misalnya saling bekerja sama, mempertanyakan asumsi, dan memberikan sudut pandang antar teman kelompok (Ifeoma dan Oge, 2013) dan adanya pertanyaan-pertanyaan guru dalam meningkatkan kemampuan siswa dalam menafsirkan data, memahami penemuan (Sothayapetch et al., 2013). Hal ini terbukti hasil penelitian SSIq dan GI mengalami peningkatan dari ulangan 1 sampai 4 pada SSIq, dan 1 sampai 3 pada GI, hal ini karena SSIq dan GI melibatkan siswa untuk melakukan proses memahami (C2), analisis (C4), dan refleksi (C5) (Anderson \& Krathwohl, 2016; Laal \& Ghodsi, 2012; Zeidler \& Nichols, 2009). Namun, Pembelajaran SSIq berbasis isu menjadikan sarana siswa terhadap keragaman perspektif dari laporan ilmiah (artikel penelitian), sedangkan SI siswa terfasilitasi untuk membaca dari perspektif yang telah disajikan dan keterampilan kognitif hanya pada batas analisis (C4) (Liewellyn, 2013).

Kegiatan investigasi pada inkuiri dapat mengembangkan kemampuan siswa dalam menfasirkan informasi, memprediksi, mengukur, mengkoordinasi, dan mengorganisasi data. Siswa juga didorong untuk mengorganisasi hasil temuan dalam bentuk diagram, grafik, tabel, dan grafik (Watters \& Diezmann, 2004) sehingga dapat menghasilkan sebuah kesimpulan berdasarkan data yang telah tersedia (Liewellyn, 2013). GI dan SI dapat meningkatkan keefektifan dan dukungan pembelajaran (Akyol, Garrison, \& Ozden, 2009) yakni meningkatkan interaksi langsung dengan materi pembelajaran, memberikan fasilitas diskusi dengan guru dan memberikan umpan balik, serta memfasilitasi siswa untuk berkolaborasi, dan dapat mengefektifkan waktu pembelajaran (Baum, Ma, \& Payea, 2013; Franco \& Almeida, 2015). Pada investigasi GI dan SI lebih menekankan pembelajaran dengan memaksimalkan aktivitas siswa. GI sebagai dasar penelitian menuntut siswa untuk menyusun prosedur penelitian secara mandiri dan SI merupakan level inkuiri yang terfasilitasinya prosedur penelitian oleh guru (Banchi \& Bell, 2008; Liewellyn, 2013).

Proses pembelajaran telah didorong untuk mengevaluasi keakuratan dan kevalidan informasi dari berbagai isu-isu di kalangan masyarakat dari berbagai sumber (internet dan buku) dan aktivitas (survei hingga wawancara) dengan menggunakannya rumusan masalah sebagai investigasi dalam rangka pemikiran analisis (C4) pada tahapan asesmen (Anderson \& Krathwohl, 2016; Lai, 2011; Zeidler, Sadler, Simmons, \& Howes, 2005). Begitu pula pada kemampuan mengevaluasi (C5) dan mencipta (C6) pada SSIq memiliki pengaruh berbeda signifikan dengan GI dan SI dengan proses kognitif yang menjadikan sarana untuk meningkatkan kemandirian siswa tentang beragam perspektif secara kritis dan memberi kesempatan mengevaluasi dalam merumuskan masalah secara ilmuwan (Banchi \& Bell, 2008; Sribekti et al., 2016). Sebaliknya, tidak ada beda yang signifikan antara GI dan SI sebagai proses kognitif yang dibatasinya kemandirian dan ruang lingkup fenomena sebagai evaluasi belajar minim kontekstual dan nyata. Permasalahan siswa pada sebagian besar adalah rendahnya pengetahuan mengenai tahapan apa saja yang diperlukan dalam menemukan informasi dan aturan menggunakan isu-isu secara etis dan legal yang berdampak pada sulitnya siswa.

Keterbatasan pada penelitian ini adalah terbatasnya kompetensi yang efektif pada tingkat menengah yang melibatkan socio scientific dan minimnya durasi waktu investigasi pada kelas X SMA pada pelajaran Biologi dalam jangka waktu satu semester. Penelitian lebih lanjut dapat melakukan peningkatan kemampuan berpikir tingkat tinggi atau HOTS (high order thinking skill) yang mencakup C4 (menganalisis) hingga C6 (mencipta) yang juga dalam meningkatkan keterampilan berpikir kritis dan pemecahan masalah.

\section{SIMPULAN}

Pembelajaran SSIq, GI, dan SI signifikan dapat meningkatkan kemampuan kognitif pada siswa SMA. SSIq dan GI lebih efektif dari pada SI. Indikator yang mengalami peningkatan signifikan dengan ukuran efek besar pada kelas SSIq dan GI terletak pada indikator menganalisis, merancang dan mencipta. Kemampuan kognitif siswa lebih efektif dapat menerapkan strategi SSIq, GI, dan SI dengan kegiatan persepsi kontekstual sebagai kajian investigasi yang lebih intensif. Selain itu, pengukuran kognitif dapat diimprovisasi dari indikator inkuiri ke dalam indikator kognitif dan ditingkatkan HOTS (high order thinking skill) yang juga mencakup keterampilan berpikir kritis dan pemecahan masalah siswa.

\section{DAFTAR RUJUKAN}

Abdurrahman, A. (2018). Efektivitas dan Kendala Pembelajaran Sains Berbasis Inkuiri terhadap Capaian Dimensi Kognitif Siswa: Meta Analisis. Tadris: Jurnal Keguruan dan Ilmu Tarbiyah, 2(1), 1. https://doi.org/10.24042/tadris.v2i1.1206

Aikenhead, G. (2007). Expanding the Research Agenda for Scientific Literacy. Promoting Scientific Literacy: Science Education Research in Transaction, (Vision I), 64-71.

Akyol, Z., Garrison, D. R., \& Ozden, M. Y. (2009). Development of a Community of Inquiry in Online and Blended Learning contexts. Procedia - Social and Behavioral Sciences, 1(1), 1834-1838. https://doi.org/10.1016/j.sbspro.2009.01.324

American Association of school. (2007). Standards for the 21st Century Learner. Chicago. IL: American Library Association.

Amien, M. (1988). Mengajarkan Ilmu Pengetahuan Alam (IPA) dengan menggunakan Metode Discovery dan Inquiry. Jakarta: Proyek Pengembangan Lembaga Pendidikan Tenaga Kependidikan.

Anam, R. S. (2016). Efektivitas dan Pengaruh Model Pembelajaran Inkuiri pada Pembelajaran IPA di Sekolah Dasar. Mimbar Sekolah Dasar, 2(1), 80-89. https://doi.org/10.17509/mimbar-sd.v2i1.1334

Baum, S., \& Ma, J. (2013). The Benefits of Higher Education for Individuals and Society. Trends in Higher Education Series. 
Brookhart, S. (2010). How To Assess Higher Order Thinking Skills In Your Classroom. United States of Amerika: ASCD Member Book.

Budiyono, A., \& Hartini, H. (2018). Pengaruh Model Pembelajaran Inkuiri Terbimbing terhadap Keterampilan Proses Sains Siswa SMA. Wacana Didaktika, 4(2), 141-149. https://doi.org/10.31102/wacanadidaktika.4.2.141-149

Burek, K. (2012). The Impact of Socioscientific Issues Based Curriculum Involving Environmental Outdoor Education for Fourth Grade Students. Unpublished Dissertation. University of South Florida

Chu, S. K. W., Tse, S. K., \& Chow, K. (2011). Using Collaborative Teaching and Inquiry Project-Based Learning to Help Primary School Students Develop Information Literacy and Information Skills. Library and Information Science Research, 33(2), 132-143. https://doi.org/10.1016/j.lisr.2010.07.017

Education, D. (2015). Directed Inquiry versus Guided Inquiry. Discovery Education Science.

Franco, A., \& Almeida, L. S. (2015). Real-World Outcomes and Critical Thinking: Differential Analysis by Academic Major and Gender. Paideia, 25(61), 173-181. https://doi.org/10.1590/1982-43272561201505

Karisan, D., \& Zeidler, D. L. (2016). Contextualization of Nature of Science Within the Socioscientific Issues Framework: A Review of Research. International Journal of Education in Mathematics, Science and Technology, 5, 139-152. https://doi.org/10.18404/ijemst.270186

Kementerian Pendidikan dan Kebudayaan. (2016). Jendela Pendidikan dan Kebudayaan Kurikulum 2013. In Kementerian Pendidikan dan Kebudayaan (3rd ed.). https://doi.org/10.1016/0031-9422(91)83742-4

Keselman, A. (2003). Supporting Inquiry Learning by Promoting Normative Understanding of Multivariable Causality. Journal of Research in Science Teaching, 40(9), 898-921. https://doi.org/10.1002/tea.10115

Kim, M., \& Tan, A. L. (2011). Rethinking Difficulties of Teaching Inquiry-Based Practical Work: Stories from Elementary PreService Teachers. International Journal of Science Education, 33(4), 465-486. https://doi.org/10.1080/09500691003639913

Kinikin, J., \& Hench, K. (2013). Poster Presentations as an Assessment Tool in a Third/College-Level Information Literacy Course: an Effective Method of Measuring Student Understanding of Library Research Skills. Journal of Information Literacy, 6(2). https://doi.org/10.11645/6.2.1698

Laal, M., \& Ghodsi, S. M. (2012). Benefits of Collaborative Learning. Procedia - Social and Behavioral Sciences, 31(May 2014), 486-490. https://doi.org/10.1016/j.sbspro.2011.12.091

Lee, W. J., Kim, H. Y., Fl, T., \& Jeong, A. (2010). The Effects of Guided Inquiry Questions on Students' Critical Thinking Skills and Satisfaction in Online Argumentation. 156-162.

Liewellyn, D. (2013). Teaching High School Science Through Inquiry and Argumentation. USA: Saga Publication.

Şen, Ş., Yılmaz, A., \& Geban, Ö. (2015). The Effects of Process Oriented Guided Inquiry Learning Environment on Students' Self-Regulated Learning Skills. Problems of Education in the 21st Century, 66, 54-66.

Sothayapetch, P., Lavonen, J., \& Juuti, K. (2013). Primary School Teachers' Interviews Regarding Pedagogical Content Knowledge (PCK) and General Pedagogical Knowledge (GPK). Uropearn Journal of Science and Mathematics Eduation, $1(2), 84-105$.

Sribekti, A., Ibrohim., \& Hidayat, A. (2016). Peningkatan Keterampilan Proses Sains dan Hasil Belajar Kognitif Siswa Kelas VII SMP Negeri 1 Selorejo menggunakan Perangkat Pembelajaran Ekosistem. Jurnal Pendidikan: Teori, Penelitian, dan Pengembangan, 1(8), 1575-1580.

Susilowati, H., Rambitan, V. M., \& Ruchaemi, A. (2017). Pengaruh Model Pembelajaran Inkuiri Terbimbing Berbasis Potensi Daerah terhadap Siswa pada Materi Pencemaran Lingkungan. Jurnal Pendidikan: Teori, Penelitian, dan Pengembangan, 2(10), 1-10.

Wang, Yingxu \& Ruhe, G. (2007). The Cognitive Process of Decision Making. Int'l Journal of Cognitive Informatics and Natural Intelligence, 1(June), 73-85.

Watters, J. J., \& Diezmann, C. M. (2004). Reforming Education : The Pursuit of Learning Through Authentic Inquiry in Mathematics, Science, and Technology. Trends in Technology Education Research

Yulaikah, S., \& Alfindasari, D. (2016). The Integration of Scientific Inquiry with The Biology Teacher's Professional Competencies to The Study of Biology In The 21 st Century. Research Report, 550-560.

Zeidler, D. L., \& Nichols, B. H. (2009). Socioscientific issues: Theory and practice. Journal of Elementary Science Education, 21(2), 49-58. https://doi.org/10.1007/BF03173684

Zeidler, D. L., Sadler, T. D., Simmons, M. L., \& Howes, E. V. (2005). Beyond STS: A Research-Based Framework for Socioscientific Issues Education. Science Education, 89(3), 357-377. https://doi.org/10.1002/sce.20048

Zo'bi, A. S. (2014). The Effect of Using Socio-Scientific Issues Approach in Teaching Environmental Issues on Improving the Students' Ability of Making Appropriate Decisions Towards these Issues. International Education Studies, 7(8), 113123. https://doi.org/10.5539/ies.v7n8p113 